\title{
Persistent molecular remission of refractory acute myeloid leukemia with inv(16)(p13.1q22) in an elderly patient induced by cytarabine ocfosfate hydrate
}

\author{
Masahisa Arahata ${ }^{1 *}$, Yukihiro Shimizu', Hidesaku Asakura² and Shinji Nakao ${ }^{3}$
}

\begin{abstract}
The prognosis of relapsed acute myeloid leukemia (AML) in elderly patients is dismal, even if the AML exhibits a good prognostic karyotype, such as inv(16)(p13.1q22). We present a 72-year-old female with AML with inv(16) (p13.1q22) who suffered five episodes of relapse with temporary complete remission. Maintenance chemotherapy with oral cytarabine ocfosfate hydrate eventually produced persistent molecular complete remission of her AML that had not been induced by conventional regimens including intensive chemotherapy and low dose cytarabine therapy. The high level of tolerability to oral cytarabine ocfosfate hydrate may offer elderly patients with this type of AML a good chance for a cure.
\end{abstract}

Keywords: Cytarabine ocfosfate hydrate, Acute myeloid leukemia, Inv(16)(p13.1q22), Refractory, Elderly

\section{Introduction}

Acute myeloid leukemia (AML) with inv(16)(p13.1q22) is characterized by a favorable prognosis and good response to treatment with cytarabine [1]. The strategy of treatment for AML with $\operatorname{inv}(16)(\mathrm{p} 13.1 \mathrm{q} 22)$ is based on a series of intensive chemotherapy, which is considered more curable than prolonged maintenance chemotherapy with low-dose anti-leukemic agents even in the elderly [2-4]. On the other hand, low-dose cytarabine therapy (LDAC) is recommended for elderly patients with AML who are not considered suitable for intensive chemotherapy [5-8], but LDAC can rarely induce persistent remission [9]. Once they relapse, their prognosis is usually dismal, even if the AML is associated with inv (16)(p13.1q22) [10,11].

\section{Case presentation}

In December 2006, a 72-year-old female was admitted to our hospital presenting with general malaise and dyspnea. A physical examination revealed anemic palpebral

\footnotetext{
* Correspondence: rqxhf297@yahoo.co.jp

'Department of Internal Medicine, Nanto Municipal Hospital, 938 Inami,

Nanto, Toyama 932-0211, Japan

Full list of author information is available at the end of the article
}

conjunctiva and purpura of the extremities. The complete blood count indicated severe anemia and thrombocytopenia as well as mild leukocytosis with $22.5 \%$ blast cells (Additional file 1). A bone marrow examination showed a total nucleated cell count of $41,000 / \mu \mathrm{L}$ with 67.0\% blasts (Additional file 2: Figure S1A). A cytogenetic analysis of the bone marrow cells with G-banding showed 46,XX,inv(16)(p13.1q22) in all 20 dividing cells (Additional file 2: Figure S1B). Based on these findings, the patient was diagnosed as having AML with inv(16)(p13.1q22).

The patient achieved complete remission (CR) after one course of induction chemotherapy comprising behenoyl cytarabine and daunorubicin according to a study protocol [12] (Table 1). However, the AML relapsed four months after the completion of the last cycle of consolidation therapy. Re-induction chemotherapy using the same regimen as the first induction induced a second CR. Thereafter, the patient suffered four further episodes of relapse with temporary remission (Figure 1). The failure to achieve durable remission even with high-dose consolidation therapy and its toxicities prompted us to select palliative care with LDAC at the third relapse. After achieving the sixth CR, the patient declined further treatment with LDAC due to toxicity. Therefore, oral 
Table 1 Chemotherapy regimens and adverse events in the present case

\begin{tabular}{|c|c|c|c|c|c|c|c|c|c|c|c|c|c|}
\hline & \multirow[b]{2}{*}{ Chemotherapy } & \multirow[b]{2}{*}{ No. } & \multirow[b]{2}{*}{ Regimen } & \multirow[b]{2}{*}{ PS } & \multirow[b]{2}{*}{ BI } & \multicolumn{6}{|c|}{ Grade of adverse event* } & \multirow[b]{2}{*}{$B W(\mathbf{k g})$} & \multirow[b]{2}{*}{ Complications } \\
\hline & & & & & & Neutropenia & $\begin{array}{c}\text { FN or } \\
\text { infecton }\end{array}$ & Anemia & Thrombocytopenia & Anorexia & $\begin{array}{l}\text { Weight } \\
\text { loss }\end{array}$ & & \\
\hline \multirow[t]{9}{*}{ Onset to 1 st $C R$} & \multirow[t]{2}{*}{ Induction } & \multirow[t]{2}{*}{1} & BHAC $200 \mathrm{mg} / \mathrm{m}^{2}$ IV day 1-8 & \multirow[t]{2}{*}{3} & \multirow[t]{2}{*}{100} & \multirow[t]{2}{*}{4} & \multirow[t]{2}{*}{3} & \multirow[t]{2}{*}{4} & \multirow[t]{2}{*}{4} & \multirow[t]{2}{*}{3} & \multirow[t]{2}{*}{1} & \multirow[t]{2}{*}{44.4} & \\
\hline & & & DNR $40 \mathrm{mg} / \mathrm{m}^{2}$ IV day $1-3$ & & & & & & & & & & \\
\hline & \multirow[t]{7}{*}{ Consolidation } & \multirow[t]{2}{*}{2} & BHAC $200 \mathrm{mg} / \mathrm{m}^{2} \mathrm{IV}$ day $1-5$ & \multirow[t]{2}{*}{2} & \multirow[t]{2}{*}{100} & \multirow[t]{2}{*}{4} & \multirow[t]{2}{*}{3} & \multirow[t]{2}{*}{4} & \multirow[t]{2}{*}{4} & 3 & 1 & 41.6 & Sepsis \\
\hline & & & MIT 7 mg/m² IV day 1-3 & & & & & & & & & & \\
\hline & & 3 & BHAC $200 \mathrm{mg} / \mathrm{m}^{2}$ IV day $1-5$ & 1 & 100 & 4 & 3 & 3 & 3 & 3 & 1 & 40.8 & \\
\hline & & & DNR $25 \mathrm{mg} / \mathrm{m}^{2}$ IV day $1-2$ & & & & & & & & & & \\
\hline & & & ETP $100 \mathrm{mg} / \mathrm{m}^{2}$ IV day $1-3$ & & & & & & & & & & \\
\hline & & 4 & BHAC $200 \mathrm{mg} / \mathrm{m}^{2}$ IV day $1-5$ & 1 & 100 & 4 & 3 & 2 & 2 & 2 & 1 & 40.5 & \\
\hline & & & ACR $10 \mathrm{mg} / \mathrm{m}^{2} \mathrm{IV}$ day $1-5$ & & & & & & & & & & \\
\hline 1st relapse to & Induction & 5 & BHAC $200 \mathrm{mg} / \mathrm{m}^{2}$ IV day $1-8$ & 4 & 55 & 4 & 3 & 4 & 3 & 3 & 2 & 39.0 & Osteoporotic lumbar \\
\hline & & & DNR $40 \mathrm{mg} / \mathrm{m}^{2}$ IV day $1-3$ & & & & & & & & & & $\begin{array}{l}\text { compression tracture } \\
\text { Pulmonary Aspergillosis }\end{array}$ \\
\hline & Consolidation & 6 & BHAC $200 \mathrm{mg} / \mathrm{m}^{2}$ IV day 1-6 & 2 & 100 & 4 & 3 & 3 & 2 & 2 & 2 & 38.5 & \\
\hline & & & DNR $40 \mathrm{mg} / \mathrm{m}^{2} \mathrm{IV}$ day $1-3$ & & & & & & & & & & \\
\hline & & 7 & Ara-C $1 \mathrm{~g} / \mathrm{m}^{2} \mathrm{IV} \times 2$ day $1-5$ & 1 & 100 & 4 & 3 & 4 & 3 & 3 & 3 & 36.9 & \\
\hline $\begin{array}{l}\text { 2nd relapse to } \\
3 \text { rd CR }\end{array}$ & Induction & 8 & $\begin{array}{l}\text { LDAC day } 1-14 \text { with M-CSF } \\
\text { day } 15-28\end{array}$ & 3 & 100 & 4 & 3 & 3 & 4 & 3 & 3 & 36.5 & \\
\hline & & 9 & $\begin{array}{l}\text { LDAC day 1-14 with M-CSF } \\
\text { day 1-14 }\end{array}$ & 2 & 100 & 4 & None & 3 & 4 & 3 & 3 & 34.9 & \\
\hline & Consolidation & 10 & Same as \# 9 & 1 & 100 & 3 & None & 3 & 3 & 3 & 3 & 35.2 & \\
\hline & & 11 & Same as \# 9 & 1 & 100 & 3 & None & 3 & 3 & 3 & 3 & 36.4 & \\
\hline & & 12 & Same as \# 9 & 1 & 100 & 3 & None & 4 & 3 & 3 & 3 & 36.4 & \\
\hline & & 13 & Same as \# 9 & 1 & 100 & 2 & None & 3 & 3 & 3 & 2 & 37.5 & \\
\hline $\begin{array}{l}\text { 3rd relapse to } \\
\text { 4th CR }\end{array}$ & Induction & 14 & $\begin{array}{l}\text { LDAC day 1-14 with M-CSF } \\
\text { day 1-14 }\end{array}$ & 1 & 100 & 4 & 3 & 3 & 4 & 3 & 2 & 37.5 & \\
\hline & & & VPA 600 mg/day PO & & & & & & & & & & \\
\hline & & 15 & $\begin{array}{l}\text { LDAC day } 1-12 \text { with M-CSF } \\
\text { day 1-14 }\end{array}$ & 1 & 100 & 3 & None & 3 & 3 & 3 & & & \\
\hline & & & VPA 600 mg/day PO & & & & & & & & & & \\
\hline & Consolidation & 16 & Same as \# 15 & 1 & 100 & 3 & None & 3 & 3 & 3 & 1 & 41.3 & \\
\hline & & 17 & $\begin{array}{l}\text { LDAC day } 1-10 \text { with M-CSF } \\
\text { day } 1-14\end{array}$ & 1 & 100 & 3 & 3 & 2 & 3 & 3 & 2 & 39.1 & \\
\hline & & & VPA 600 mg/day PO & & & & & & & & & & \\
\hline
\end{tabular}


Table 1 Chemotherapy regimens and adverse events in the present case (Continued)

\begin{tabular}{|c|c|c|c|c|c|c|c|c|c|c|c|c|c|}
\hline & & 18 & Same as \# 17 & 1 & 100 & 3 & 3 & 2 & 3 & 3 & 2 & 39.4 & \\
\hline & & 19 & Same as \# 17 & 1 & 100 & 3 & None & 3 & 3 & 3 & 1 & 40.6 & \\
\hline \multirow[t]{13}{*}{$\begin{array}{l}\text { 4th relapse to } \\
5 \text { th } C R\end{array}$} & Induction & 20 & $\begin{array}{l}\text { LDAC day } 1-10 \text { with M-CSF } \\
\text { day } 1-14\end{array}$ & 3 & 95 & 4 & 3 & 4 & 4 & 3 & 1 & 42.4 & \\
\hline & & 21 & SPAC $200 \mathrm{mg} /$ day PO day 1-14 & 1 & 95 & None & None & 3 & None & 2 & & & \\
\hline & & & G-CSF $100 \mu \mathrm{g}$ SC day 1-14 & & & & & & & & & & \\
\hline & & 22 & Same as \# 21 & 1 & 95 & 3 & None & 2 & 2 & 1 & 1 & 41.2 & \\
\hline & & 23 & $\begin{array}{l}\text { LDAC day } 1-10 \text { with M-CSF } \\
\text { day } 1-14\end{array}$ & 2 & 100 & 4 & 3 & 4 & 4 & 3 & 1 & 42.0 & \\
\hline & & 24 & $\begin{array}{l}\text { LDAC day } 1-12 \text { with M-CSF } \\
\text { day } 1-14\end{array}$ & 3 & 100 & 4 & 3 & 4 & 4 & 3 & 1 & 41.6 & \\
\hline & & 25 & $\begin{array}{l}\text { LDAC day } 1-12 \text { with G-CSF } \\
\text { day } 1-12\end{array}$ & 3 & 100 & 4 & 3 & 4 & 4 & 3 & 1 & 42.2 & \\
\hline & & & ACR $14 \mathrm{mg} / \mathrm{m}^{2}$ IV day $1-4$ & & & & & & & & & & \\
\hline & & 26 & Same as \# 25 & 2 & 100 & 3 & 3 & 3 & 3 & 3 & 1 & 41.7 & \\
\hline & Consolidation & 27 & Same as \# 25 & 1 & 100 & 3 & None & 3 & 3 & 2 & & & \\
\hline & & 28 & Same as \# 25 & 1 & 100 & 4 & None & 3 & 3 & 2 & 2 & 39.6 & \\
\hline & & 29 & Same as \# 25 & 1 & 100 & 4 & None & 3 & 4 & 2 & 2 & 39.5 & \\
\hline & & 30 & Same as \# 25 & 1 & 100 & 4 & None & 3 & 4 & 2 & & & \\
\hline \multirow[t]{10}{*}{$\begin{array}{l}\text { 5th relapse to } \\
\text { 6th } C R\end{array}$} & Induction & 31 & $\begin{array}{l}\text { LDAC day } 1-12 \text { with G-CSF } \\
\text { day } 1-12\end{array}$ & 3 & 5 & 4 & 3 & 4 & 4 & 3 & 1 & 40.8 & Depression \\
\hline & & & ACR $14 \mathrm{mg} / \mathrm{m}^{2}$ IV day $1-4$ & & & & & & & & & & \\
\hline & & 32 & $\begin{array}{l}\text { MTX } 15 \text { mg + Ara-C 40mg + PSL } \\
10 m g \text { IT day -1 }\end{array}$ & 4 & 5 & 4 & 3 & 4 & 4 & 4 & & & $\begin{array}{l}\text { Traumatic lumbar } \\
\text { compression fracture }\end{array}$ \\
\hline & & & $\begin{array}{l}\text { LDAC day } 1-10 \text { with G-CSF } \\
\text { day } 1-12\end{array}$ & & & & & & & & & & \\
\hline & & & ACR $14 \mathrm{mg} / \mathrm{m}^{2}$ IV day $1-4$ & & & & & & & & & & \\
\hline & Consolidation & 33 & $\begin{array}{l}\text { LDAC day } 1-10 \text { with G-CSF } \\
\text { day } 1-12\end{array}$ & 3 & 5 & 4 & 3 & 3 & 3 & 3 & & & \\
\hline & & & ACR $14 \mathrm{mg} / \mathrm{m}^{2}$ IV day $1-4$ & & & & & & & & & & \\
\hline & & 34 & Same as \# 33 & 1 & 75 & 4 & None & 3 & 3 & 3 & None & 44.0 & \\
\hline & & 35 & Same as \# 33 & 1 & 90 & 4 & None & 3 & 4 & 3 & None & 44.6 & \\
\hline & Maintenance & 36 & $\begin{array}{l}\text { SPAC } 300 \text { mg/day PO day 1-7 every } \\
4-6 \text { weeks }\end{array}$ & 1 & 100 & None & None & None & None & 2 & 2 & 36.0 & Sarcopenia \\
\hline
\end{tabular}

ACR: aclarubicin hydrochloride, Ara-C: cytarabine, BHAC; behenoyl cytarabine, BI: Barthel index, BW: body weight, DNR: daunorubicin hydrochloride, ETP: etoposide, FN: febrile neutropenia, G-CSF: lenograstim 100 $\mu \mathrm{g}$ subcutaneously injected or lenograstim $250 \mu \mathrm{g}$ intravenously injected, IT: intrathecal injection, IV: intravenous injection, LDAC: cytarabine $10 \mathrm{mg} / \mathrm{m}^{2}$ subcutaneously injected twice a day, M-CSF: mirimostim 8 million units intravenously injected, MIT: mitoxantrone hydrochloride, PO: per oral, PS: performance status, SC: subctaneous injection.

*Adverse events were graded according to the Common Terminology Criteria for Adverse Events (CTCAE) version 4.03 produced by the National Cancer Institute (http://evs.nci.nih.gov/ftp1/CTCAE/About.html). 


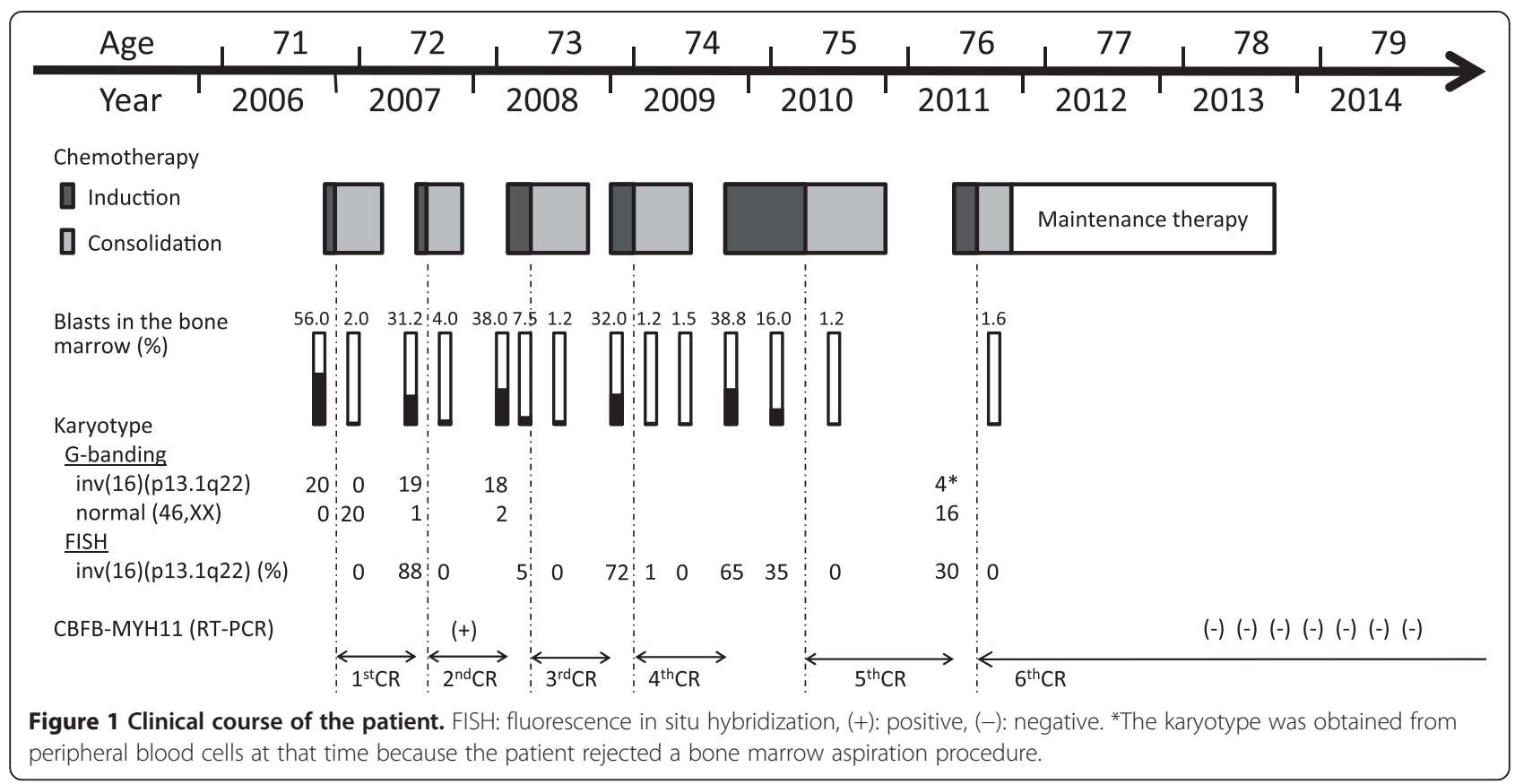

cytarabine ocfosfate hydrate (SPAC) was started in order to maintain remission in November 2011. The SPAC therapy was not associated with any significant toxicity. The CBFB-MYH11 fusion mRNA in the peripheral blood became negative after twelve courses of SPAC therapy, which was terminated in October 2013. The patient has since remained in molecular remission without chemotherapy (Figure 1).

\section{Discussion}

Our patient received lower doses of cytarabine and daunorubicin than the doses that are considered as standard doses for remission induction of AML with inv (16)(p13.1q22) nowadays, and the suboptimal doses of induction chemotherapy may be the cause of her early relapse. However, higher doses of cytarabine and daunorubicin may have put the 72-year-old woman's life in danger due to associated toxicities. The frail woman eventually went into deep remission after maintenance therapy with a cytarabine prodrug SPAC.

SPAC has been shown to be as effective and tolerable as LDAC in treatment of AML [13-15], though its usefulness of SPAC is not well recognized because it is not available outside Japan. In this case, the AML cells were considered as highly sensitive to cytarabine because of repetitive achievement of $C R$ induced by LDAC. Besides, SPAC was associated with fewer toxicities than LDAC (Table 1). LDAC requires the use of subcutaneous injections twice a day, but elderly patients often have difficulties visiting the hospital frequently. On the other hand, SPAC can be orally administered at home. These advantages enabled our patient to continue the maintenance therapy for two years and contributed to her persistent molecular remission. Thus, SPAC potentially offers a chance of cure for elderly patients with inv(16)(p13.1q22) without life threatening toxicities.

\section{Consent}

Written informed consent was obtained from the patient for publication of this case report and any accompanying images. A copy of the written consent is available for review by the Editor-in-Chief of this journal.

\section{Additional files}

Additional file 1: Table S1. Laboratory data of the patient at diagnosis. ALT: alanine aminotransferase, ALP: alkaline phosphatase, APTT: activated partial thromboplastin time, AST: aspartate aminotransferase, AT-III: antithrombin-III, CRP: C-reactive protein, $\gamma$-GTP: $\gamma$-glutamyltranspeptidase, LDH: lactate dehydrogenase, PT-INR: international normalized ratio of the prothrombin time, T-Bil: total bilirubin, T-Cho: total cholesterol.

Additional file 2: Figure S1. Smear and karyogram of bone marrow aspirates. A: May-Giemsa-stained smear $(\times 1,000)$. The blue arrows indicate myeloblasts and monoblasts. The percentage of eosinophils was elevated up to $16.0 \%$ of all nucleated cells. The immunophenotype of the blasts was CD2+, CD13+, CD33+, CD34+ and HLA-DR+ (data is not shown). B: Karyogram determined by G-banding. The red arrow indicates inv(16) (p13.1;q22).

\section{Abbreviations}

AML: Acute myeloid leukemia; CR: Complete remission; LDAC: Low-dose cytarabine therapy; SPAC: Cytarabine ocfosfate hydrate. 


\section{Competing interests}

All the authors declare that they have no competing interests.

\section{Authors' contributions}

MA is the doctor in charge of the present case and reviewed guidelines and studies regarding chemotherapy with low-dose agents in elderly patients with $\mathrm{AML}$ and wrote the manuscript. YS assisted in preparing the manuscript. $\mathrm{HA}$ and SN are medical advisers of hematology and assisted in preparing the manuscript. All authors have read and approved the final manuscript.

\section{Author details}

1Department of Internal Medicine, Nanto Municipal Hospital, 938 Inami, Nanto, Toyama 932-0211, Japan. ${ }^{2}$ Department of Internal Medicine (III), Kanazawa University Graduate School of Medical Science, Kanazawa, Japan. ${ }^{3}$ Department of Cellular Transplantation Biology, Division of Cancer Medicine, Kanazawa University Graduate School of Medical Science, Kanazawa, Japan.

Received: 27 December 2014 Accepted: 27 December 2014

Published online: 06 February 2015

\section{References}

1. Delaunay J, Vey N, Leblanc T, Fenaux P, Rigal-Huguet F, Witz F, et al. Prognosis of inv $(16) / t(16 ; 16)$ acute myeloid leukemia $(A M L)$ : a survey of 110 cases from the French AML Intergroup. Blood. 2003;102:462-9.

2. Juliusson G, Antunovic P, Derolf A, Lehmann S, Möllgård L, Stockelberg D, et al. Age and acute myeloid leukemia: real world data on decision to treat and outcomes from the Swedish Acute Leukemia Registry. Blood. 2009;113:4179-87.

3. Vey N, Coso D, Bardou VJ, Stoppa AM, Braud AC, Bouabdallah R, et al. The benefit of induction chemotherapy in patients age $>$ or $=75$ years. Cancer. 2004;101:325-31.

4. Prébet T, Boissel N, Reutenauer S, Thomas X, Delaunay J, Cahn JY, et al. Acute myeloid leukemia with translocation (8;21) or inversion (16) in elderly patients treated with conventional chemotherapy: A collaborative study of the French CBF-AML Intergroup. J Clin Oncol. 2009;27:4747-53.

5. Brandwein JM, Geddes M, Kassis J, Kew AK, Leber B, Nevill T, et al. Treatment of older patients with acute myeloid leukemia (AML): a Canadian consensus. Am J Blood Res. 2013;3:141-64.

6. O'Donnell MR, Abboud CN, Altman J, Appelbaum FR, Arber DA Attar E, et al. Acute Myeloid Leukemia. J Natl Compr Canc Netw. 2012;10:984-1021.

7. Döhner H, Estey EH, Amadori S, Appelbaum FR, Büchner T, Burnett AK, et al. Diagnosis and management of acute myeloid leukemia in adults: recommendations from an international expert panel, on behalf of the European LeukemiaNet. Blood. 2010;115:453-74.

8. Milligan DW, Grimwade D, Cullis JO, Bond L, Swirsky D, Craddock C, et al. Guidelines on the management of acute myeloid leukemia in adults. $\mathrm{Br}$ J Haematol. 2006;135:450-74

9. Burnett AK, Milligan D, Prentice AG, Goldstone AH, McMullin MF, Hills RK, et al. A comparison of low-dose cytarabine and hydroxyurea with or without all-trans retinoic acid for acute myeloid leukemia and high-risk myelodysplastic syndrome in patients not considered fit for intensive treatment. Cancer. 2007;109:1114--1124.

10. Ferrara F, Palmieri S, Mele G. Prognostic factors and therapeutic options for relapsed or refractory acute myeloid leukemia. Haematologica. 2004:89:998-1008.

11. Marcucci G, Mrózek K, Ruppert AS, Maharry K, Kolitz JE, Moore JO, et al. Prognostic factors and outcome of core binding factor acute myeloid leukemia patients with $\mathrm{t}(8 ; 21)$ differ from those of patients with inv(16): a Cancer and Leukemia Group B study. J Clin Oncol. 2005:23:5705-17.

12. Wakita A, Ohtake S, Takada S, Yamasaki F, Komatsu H, Miyazaki Y, et al. Randomized comparison of fixed-schedule versus responseoriented individualized induction therapy and use of ubenimex during and after consolidation therapy for elderly patients with acute myeloid leukemia: the JALSG GML200 Study. Int J Hematol. 2012;96:84-93.

13. Ueda T, Kamiya K, Urasaki $Y$, Wataya S, Kawai $Y$, Tsutani H, et al. Clinical pharmacology of 1-beta-D-arabinofuranosylcytosine-5'-stearylphosphate, an orally administered long-acting derivative of low-dose 1-beta-D-arabinofuranosylcytosine. Cancer Res. 1994;54:109-13.
14. Okumura H, Yoshida T, Takamatsu H, Katoh T, Murashima M, Watanabe A, et al. Treatment of acute myeloid leukemia and myelodysplastic syndrome with orally administered cytarabine ocfosfate and granulocyte colonystimulating factor. Int J Hematol. 1997;65:263-8.

15. Horikoshi A, Takei K, Hosokawa Y, Sawada S. The value of oral cytarabine ocfosfate and etoposide in the treatment of refractory and elderly AML patients. Int J Hematol. 2008;87:118-25.

\section{Submit your next manuscript to BioMed Central and take full advantage of:}

- Convenient online submission

- Thorough peer review

- No space constraints or color figure charges

- Immediate publication on acceptance

- Inclusion in PubMed, CAS, Scopus and Google Scholar

- Research which is freely available for redistribution 